\title{
Sistem Kendali Kecepatan Motor pada Mobile Robot Menggunakan PID dan Analisis Disturbance Berbasis Disturbance Observer
}

\author{
Bayu Sandi Marta ${ }^{\text {* }}$, Indra Ferdiansyah ${ }^{2}$, Fernando Ardila $^{3}$ \\ 1,2,3 Politeknik Elektronika Negeri Surabaya \\ *bayu@pens.ac.id
}

\begin{abstract}
Mobile robot's ability to maintain its speed is very important. When the robot is running and there is disturbance from outside system that affect the robot, causing the speed of the robot becomes unstable. For it is necessary to add a mechanism that is able to make the robot keep pace, one of them by giving control. This research will be built a speed control system on a mobile robot. The speed control system aims to improve performance and stability robot speed by minimizing the effect of unmeasured disturbances from outside the robot eg mechanical changes such as granting a load that can cause changes in the behavior of the system so that the necessary arrangements back to the control system. In this control system used control Proportional, Integral, Derivative (PID) and the analysis of disturbance based Disturbance Observer (DOB). PID control functions to improve motor performance robot. While $D O B$ functions to analyze the disturbance from outside robot. The results of the implementation of the Disturbance Observer to PID control produce average root mean square error value of the reference value for the speed of 19.59 rpsfor right motor and left motor is 16.66 rps. While the average root mean square error of the reference value with PID control without Disturbance Observer on the right motor is 24.47 rps and the left motor is 18.89 rps.
\end{abstract}

Keywords : mobile robot, Proportional Integral Derivatif (PID), disturbance, Disturbance Observer (DOB), robust.

\begin{abstract}
Abstrak
Kemampuan mobile robot dalam menjaga kecepatannya sangatlah penting. Ketika robot berjalan dan terdapat gangguan yang tak terukur (disturbance) dari luar sistem yang mempengaruhi robot, menyebabkan kecepatan robot menjadi tidak stabil. Untuk itu perlu ditambahkan suatu mekanisme yang mampu membuat robot menjaga kecepatannya, salah satunya dengan memberikan kontrol. Pada penelitian ini akan dibangun sebuah sistem kendali kecepatan pada mobile robot. Sistem kendali kecepatan ini bertujuan untuk meningkatkan performa robot dan stabilitas kecepatan dengan meminimalkan pengaruh gangguan yang tidak terukur dari luar robot misalnya perubahan mekanis seperti pemberian beban yang dapat menyebabkan perubahan perilaku sistem sehingga diperlukan pengaturan kembali terhadap sistem kontrol. Dalam sistem kendali ini digunakan kontrol Proportional, Integral, Derivative (PID) dan analisis gangguan (disturbance) berbasis Disturbance Observer (DOB). Kontrol PID berfungsi untuk meningkatkan performa motor robot. Sedangkan DOB berfungsi untuk analisis gangguan dari luar robot. Sehingga diharapkan dari penelitian ini dapat dihasilkan sebuah sistem kontrol yang mampu membuat robot robust terhadap disturbance dan performa robot tetap terjaga tanpa merubah pengaturan sistem kontrol kembali. Hasil implementasi Disturbance Observerke dalam kontrol PID menghasilkan nilai root mean square error rata-rata terhadap nilai acuan kecepatan sebesar 19,59 rps untuk motor kanan dan 16,66 rps untuk motor kiri. Sedangkan ratarata root mean square error terhadap nilai acuan kecepatandengan kontrol PID tanpa Disturbance Observer pada motor kanan sebesar 24,47 rps dan pada motor kiri sebesar 18,89 rps.
\end{abstract}

Kata kunci : mobil robot, PID, gangguan, observasi gangguan, kehandalan sistem

\section{Pendahuluan}

Robot adalah suatu alat mekanik yang dapat melakukan tugas fisik, baik menggunakan pengawasan dan kontrol manusia, ataupun menggunakan program yang telah didefinisikan terlebih dahulu. Berdasarkan konstruksinya robot terdiri atas berbagai macam jenis, contohnya mobile 
robot, robot manipulator, robot berkaki, dan lain-lain [1]. Dalam dunia robotika khususnya pada mobilerobot, sistem kontrol sangatlah penting.Salah satu kegunaan kontrol adalah untuk meningkatkan performa kecepatan mobile robot dan menjaga ketahanan performa robot atau robustness.Banyak metode yang digunakan dalam meningkatkan dan mempertahankan performa suatu mobile robot. Tujuannnya tidak lain adalah membuat robot menjadi lebih baik, handal, dan tahan terhadap gangguan yang mempengaruhi performa robot.Gangguan seperti kondisi jalan dan beban dinamis yang diterima robot dapat mengakibatkan ketidakpastian model plant, noise dan gangguan [2], [3]. Akibat dari ketidakpastian model tersebut akan menyebabkan performa robot menurun. Pada Disturbance Observer yang sangat diperhatikan adalah penentuan low pass filter dan model inverse nominal plant.

Pada penelitian ini, metode yang digunakan adalah kontrol Proportional Integral Derivative (PID) yang berbasisDisturbance Observer (DOB). Kontrol PID berfungsi untuk mengoptimalkan respon motor penggerak mobile robot. Pada kontrol PID yang sangat diperhatikan adalah menentukan nilai konstantanya, karena konstanta akan berpengaruh terhadap performa robot. Sedangkan Disturbance Observer berfungsi sebagai analisis gangguan yang diterima robot untuk mempertahankan respon motor yang dikontrol oleh PID.

\section{Metoda Penelitian}

\subsection{Kontrol PID}

Proportional-integral-derivative

controller (PID controller) adalah sebuah generik kontrol loop dengan mekanisme umpan balik. Secara luas digunakan dalam industri sistem kontrol. PID control digunakan untuk memperbaiki kesalahan antara variable proses dan set point yang diinginkan dengan menghitung kemudian melakukan koreksi yang dapat menyesuaikan proses dengan cepat dan tepat [1].

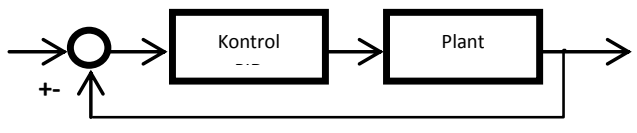

Gambar 1. Struktur Kontrol PID

Perhitungan PID control melibatkan tiga parameter yang terpisah yaitu nilai proporsional, nilai integral dan nilai derivatif. Nilai proporsional menentukan reaksi terhadap kesalahan saat ini, nilai integral menentukan reaksi berdasarkan jumlah kesalahan baru-baru ini dan nilai derivatif ditentukan dari reaksi yang didasarkan pada tingkat dimana kesalahan telah berubah [4]. Rumus umum $P I D$ adalah sebagai berikut :

$U=-K_{p} e+K_{i} \int e d t+K_{d} \frac{d e}{d t}$

dimana :

$$
\begin{aligned}
& \mathrm{Kp}=\text { Konstanta Proportional } \\
& \mathrm{Ki}=\text { Konstanta Integral } \\
& \mathrm{Kd}=\text { Konstanta derivative }
\end{aligned}
$$

Secara umum kontrol PID dapat dipisah dimana kontrol $\mathrm{P}$ dapat berdiri sendiri ataupun dipasangkan dengan kontrol I saja ataupun kontrol D saja. Dari ketiga parameter tersebut dapat diketahui pengaruh parameter PID tehadap respon sistem yang dapat ditunjukkan pada tabel 1.

Tabel 1. Tanggapan sistem terhadap perubahan parameter PID.

\begin{tabular}{ccccc}
\hline Gain & $\begin{array}{c}\text { Rise } \\
\text { Time }\end{array}$ & Overshoot & $\begin{array}{c}\text { Settling } \\
\text { TIme }\end{array}$ & $\begin{array}{c}\text { Steady } \\
\text { State } \\
\text { error }\end{array}$ \\
\hline P & Menurun & Meningkat & $\begin{array}{c}\text { Perubahan } \\
\text { Kecil }\end{array}$ & Menurun \\
I & Menurun & Meningkat & $\begin{array}{c}\text { Meningkat } \\
\text { Menurun }\end{array}$ & $\begin{array}{c}\text { Hilang } \\
\text { Perubahan } \\
\text { Kecil }\end{array}$ \\
D & $\begin{array}{c}\text { Perubahan } \\
\text { Kecil }\end{array}$ & Menurun & & \\
& & & &
\end{tabular}

\subsection{Disturbance Observer}

Disturbance Observer atau yang biasa disebut dengan DOB merupakan suatu mekanisme pengontrolan yang berada pada loop internal dari sebuah plant. Pengendalian bersifat robust digunakan untuk mengendalikan plant di lingkungan dimana ketidakpastian model dan gangguan berada. Pengendalian berbasis disturbance observer 
yang menghasilkan sinyal akselerasi ke plant adalah pengendali yang bersifat robust. Sistem kendali ini membentuk perilaku input-output bersifat robust dengan menghilangkan gangguan $(d)$ terhadap plant atau noise (e) yang mempengaruhi sensor [3], [5].

Metode ini biasanya menggunakan struktur dual loop, yaitu loop internal dan loop eksternal. Loop internal didesain untuk membuat sistem mampu meredam disturbance dan ketidakpastian parameter, sedangkan loop eksternal didesain untuk meningkatkan performa sistem secara keseluruhan.

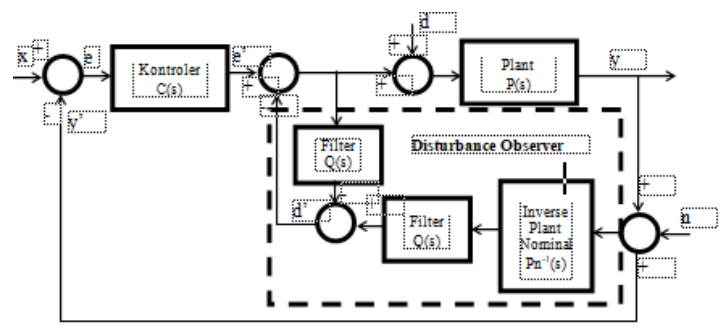

Gambar 2. Struktur Disturbance Observer

Berdasarkan arsitektur di atas, kontroler loop internal menghasilkan sinyal kontrol korektif untuk meredam disturbance semaksimal mungkin, untuk membuat plant aktual menjadi model nominal. Disturbance didefinisikan sebagai jumlahan dari sinyal external disturbance, seperti gesekan dan semua sinyal yang muncul akibat dari perbedaan antara plant actual dengan model nominal, seperti ketidak pastian pemodelan dan variasi parameter [6].

Idealnya, DOB akan melemahkan disturbance pada frekuensi rendah dan membuat plant yang dikontrol oleh loop eksternal mendekati model nominal. Kemampuan ini dapat ditunjukkan dengan memperhatikan fungsi alih-fungsi alih berikut [7]:

$$
\begin{aligned}
& G_{u y}(s)=\frac{P(s) P_{n}(s)}{P_{n}(s)+Q(s)\left(P(s)-P_{n}(s)\right)} \\
& G_{d y}(s)=\frac{P(s) P_{n}(s)(1-Q(s))}{P_{n}(s)+Q(s)\left(P(s)-P_{n}(s)\right)} \\
& G_{e y}(s)=\frac{P(s) Q(s)}{P_{n}(s)+Q(s)\left(P(s)-P_{n}(s)\right)}
\end{aligned}
$$

Dari ketiga fungsi alih diatas dapat dilihat bahwa desain DOB untuk menentukan performa penolakan disturbancetergantung dari pemilihan filter Q. Perilaku ketiga fungsi alih sistem diatas ketika nilai filter $Q$ mendekati 1 pada low frequency akan menunjukkan efek DOB pada sistem sebagai berikut [4]:

1. $\mathrm{G}_{\mathrm{uy}}(\mathrm{s}) \approx \mathrm{P}_{\mathrm{n}}(\mathrm{s})$, hal ini berarti dinamika sistem dari u ke y akan menjadi sama seperti model nominal.

2. $\mathrm{G}_{\mathrm{dy}}(\mathrm{s}) \approx 0$, hal ini menunjukkan bahwa pada frekuensi rendah disturbance yang ada akan diredam.

3. $\mathrm{G}_{\mathrm{ey}}(\mathrm{s}) \approx \mathrm{P}_{\mathrm{n}}(\mathrm{s})$, hal ini menunjukkan bahwa sensor noiseakan tetap diteruskan. ntuk penentuan filter $\mathrm{Q}(\mathrm{s})$ dalam perancangan DOB digunakan filter low pass. Struktur filter $\mathrm{Q}(\mathrm{s})$ yang banyak digunakan dalam DOB adalah filter binomial dinyatakan pada persamaan 5 .

$Q(s)=\frac{1+\sum_{k=1}^{N-r} a_{k}(\tau s)^{k}}{1+\sum_{k=1}^{N} a_{k}(\tau s)^{k}}$

dimana :

$$
\begin{aligned}
& \mathrm{N}=\text { orde dari } \mathrm{Q}(\mathrm{s}) \\
& \mathrm{r}=\text { derajat relatif dari } \mathrm{Q}(\mathrm{s}) \\
& \mathrm{w}_{\mathrm{c}}=1 / \tau=\text { frekuensi cut-off } \mathrm{Q}(\mathrm{s}) \\
& \tau=\text { Time Constant }
\end{aligned}
$$

Dengan adanya blok Disturbance Observer, model plant actual secara tidak langsung dipaksa oleh Disturbance Observer untuk menjadi seperti model nominal plant. Sehingga apabila terdapat gangguan yang menyebabkan perubahan struktur model plant, tidak berpengaruh terhadap struktur dari kontrol karena Disturbance Observer akan menghasilkan nilai estimasi gangguan untuk mengurangi efek gangguan pada plant.

\subsection{Perancangan Sistem}

Secara garis besar, rancangan "Sistem Kontrol Kecepatan Mobile Robot Menggunakan PID dan Analisis Disturbance Berbasis Disturbance Observer" adalah seperti pada Gbr 3. Dimana ada dua motor yang 
berfungsi sebagai penggerak robot secara diferensial dengan mekanik seperti yang ditunjukan pada Gbr 4. Masing - masing motor dikontrol oleh PID secara terpisah karena setiap motor memiliki karakteristik yang berbeda. Dalam perancangan sistem ini seperti terdapat suatu mekanisme pengendalian yang berasal dari internal motor yang pada penelitian ini disebut sebagai Disturbance Observer.

Tampak Atas

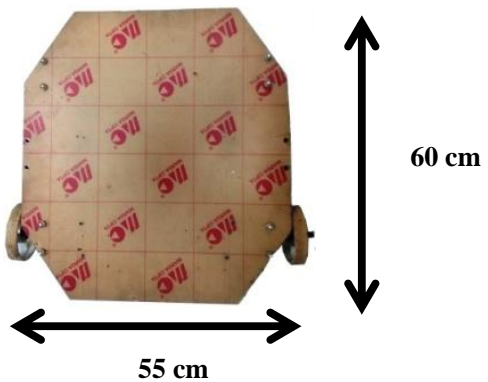

Tampak Samping

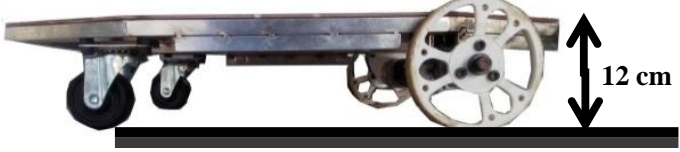

Gambar 3. Mekanik Mobil Robot

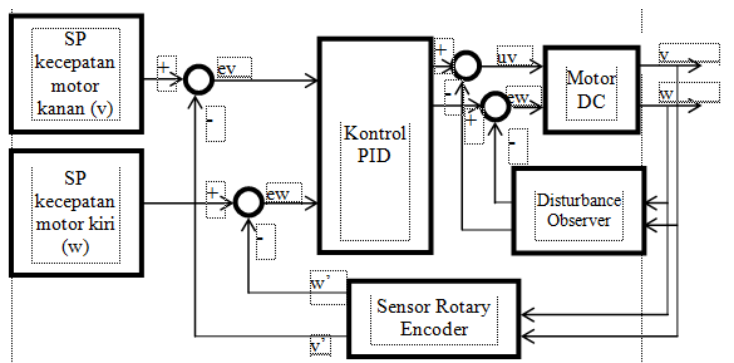

Gambar 4. Blok diagram rancangan umum sistem

Penjelasan dari blok diagram di atas adalah sebagai berikut: Dimulai dengan pembacaaan data dari sensor. Sensor rotaryencoder akan mendeteksi kecepatan putaran motor. Pendeteksian sensor menghasilkan pulsa kotak yang akan diproses oleh mikrokontroler. Di dalam mikrokontroler ini akan dilakukan kontrol kecepatan oleh kontrol PID. Selain itu di dalamnya juga terdapat proses analisis gangguan

menggunakan

Disturbance

Observer. Disturbance Observer ini akan bekerja pada bagian plant atau motor yaitu dengan mengoreksi sinyal dari sensor dan sinyal input motor sehingga menghasilkan sinyal koreksi pada input motor. Sinyal input ini digunakan untuk pengaturan kecepatan motor.

\subsubsection{Pemodelan Motor Menggunakan MATLAB}

Pada tahapan ini adalah melakukan identifikasi sistem motor yang dilakukan dengan menggunakan program Matlab melalui fungsi ident. Terlebih dahulu nilai kecepatan dan masukan tegangan disimpan kedalam suatu variabel. Estimasi yang akan dilakukan adalah mencari model fungsi alih dari data variabel yang dimasukkan pada Data Views.

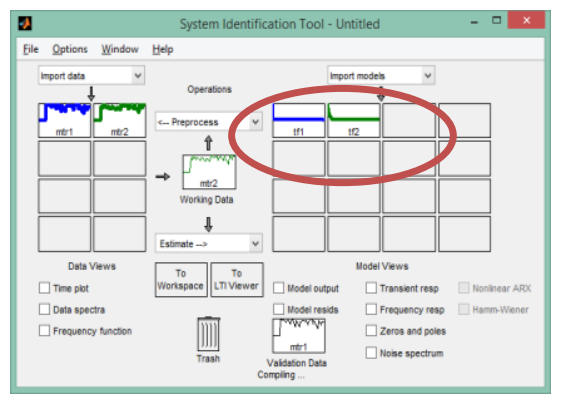

Gambar 8. Grafik Hasil Estimasi Data

Untuk mengetahui persamaan matematika dari kedua model bisa dilakukan klik dua kali pada masing-masing grafik pada bagian model. Sehingga akan diperoleh persamaan matematika seperti pada Gambar 9.
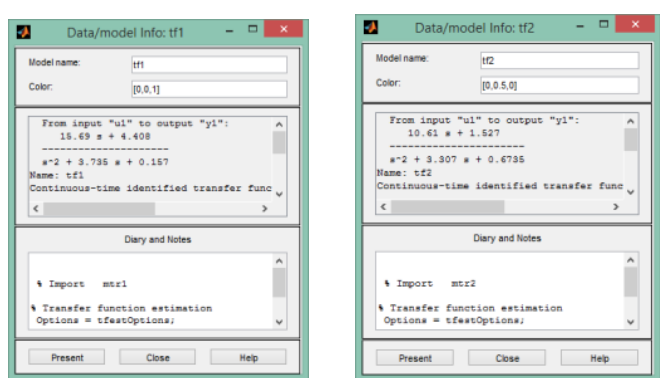

Gambar 9. Fungsi Alih Motor Kanan dan Kiri

Setelah didapatkan model persamaan matematika nominal motor kanan $\left(\mathrm{P}_{\mathrm{n}} 1\right)$ dan 
nominal motor kiri $\left(\mathrm{P}_{\mathrm{n}} 2\right)$ sebagai berikut :

$\operatorname{Pn} 1(s)=\frac{15,69 s+4.408}{s^{2}+3.735 s+0.157}$

$\operatorname{Pn} 2(s)=\frac{10.61 s+1.527}{s^{2}+3.307 s+0.6735}$

Dari persamaan 6 dan persamaan 7 selanjutnya akan digunakan untuk merancang pengendalian pada loop eksternal yang dilakukan oleh kontrol PID. Model matematik dari masing-masing motor diekspor ke Workspace Matlab. Untuk dilakukan proses tunning konstanta dari kontrol PID.

Pada penentuan konstanta kontrol PID, terdapat berbagai macam cara antara lain dengan metode Direct Systhesis, ZieglerNichols, Cohen-Coen. Selain beberapa metode tersebut terdapat cara lain untuk menentukan konstanta PID, yaitu dengan cara menggunakan fasilitas dari program Matlab yaitu fungsi pidtool. Dari fungsi tersebut dapat dilakukan tuning dan dapat secara langsung perubahan respon motor saat mengubah beberapa parameter respon motor. Proses tunning PID motor kanan dan kiri dilakukan seperti pada Gambar 10 dan Gambar 11.

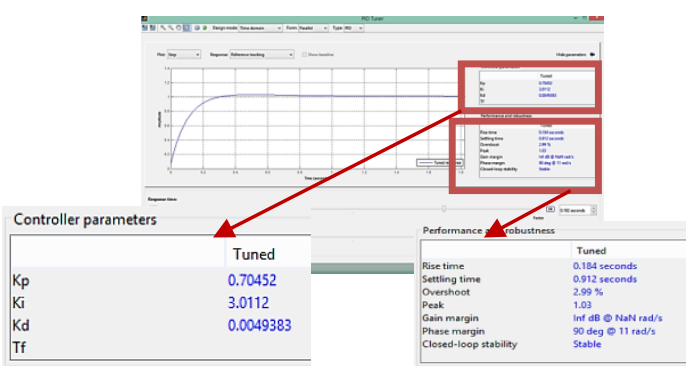

Gambar 10. Tunning Konstanta PID Motor Kanan dengan PIDTOOL

Hasil tunning konstanta PID motor kanan dengan PIDTOOL didapatkan nilai konstanta - konstanta PID Kp $=0.70452, \mathrm{Ki}=3.0112$, $\mathrm{Kd}=0.0049$. Hasil tunning ini didapatkan respon motor yang memiliki rise time $=184$ $\mathrm{ms}$, settling time $=915 \mathrm{~ms}$, presentase overshoot $=2.99 \%$, dan kesalahan kondisi steady $=0.03 \mathrm{~s}$.

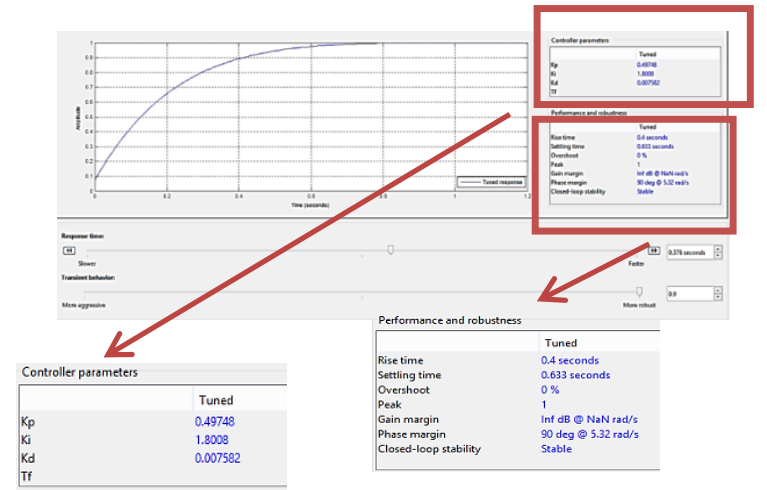

Gambar 11. Tunning Konstanta PID Motor Kiri dengan PIDTOOL

Hasil tunning konstanta PID motor kiri dengan PIDTOOL didapatkan nilai konstanta konstanta PID Kp $=0.4974, \mathrm{Ki}=1.8008, \mathrm{Kd}=$ 0.0075. Hasil tunning ini didapatkan respon motor yang memiliki rise time $=400 \mathrm{~ms}$, settling time $=633 \mathrm{~ms}$, presentase overshoot $=$ $0 \%$, dan kesalahan kondisi steady $=0$. Konstanta - konstanta yang didapatkan dari proses tunning selanjutnya digunakan sebagai parameter perancangan kontrol PID. Persamaan 8 dan persamaan 9 merupakan persamaan dalam kawasan waktu kontinyu.

$$
\begin{aligned}
& C 1(s)=\frac{0.005 s^{2}+0.7045 s+3.0112}{s} \\
& C 2(s)=\frac{0.0076 s^{2}+0.4974 s+1.8008}{s}
\end{aligned}
$$

Untuk dapat merealisasikan ke dalam bentuk pemrograman, maka persamaan waktu kontinyu tersebut harus diubah terlebih dahulu ke dalam bentuk diskrit sehingga dapat di implementasikan pada perangkat digital seperti mikrokontroler atau komputer untuk proses komputasi.

Proses diskritisasi kontrol proporsional adalah dapat ditunjukkan pada persamaan 10 .

$u(k)=K p \times e(k)$

\section{Dimana :}

$\mathrm{U}(\mathrm{k})=$ keluaran kontrol proporsional waktu sekarang

$\mathrm{Kp}=$ konstanta proporsional

$\mathrm{E}(\mathrm{k})=$ error waktu sekarang 
Proses diskritisasi kontrol integral ditunjukkan pada persamaan 11 sampai persamaan 13.

$u(k)=K i \sum_{i=0}^{k} e(i) \times T c$

$u(k)=\operatorname{KiTc} \sum_{i=0}^{k} e(i)=\operatorname{KiTc}[e(0)+$

$e(1)+\cdots+e(k-1)+e(k)$

$u(k)=\operatorname{KiTc}[e(k-1)+e(k)]$

Dimana :

$\mathrm{U}(\mathrm{k})=$ keluaran kontrol integral waktu sekarang

$\mathrm{Ki}=$ konstanta integral

Tc = waktu sampel

$\mathrm{E}(\mathrm{k})=$ error waktu sekarang

$\mathrm{E}(\mathrm{k}-1)=$ error satu detik sebelum waktu sekarang

Proses diskritisasi kontrol derivatif ditunjukkan pada persamaan 14.

$u(k)=K d \frac{e(k)-e(k-1)}{T c}$

Dimana :

$\mathrm{U}(\mathrm{k})=$ keluaran kontrol derivatif waktu sekarang

$\mathrm{Kd}=$ konstanta derivatif

$\mathrm{Tc} \quad=$ waktu sampel

$\mathrm{E}(\mathrm{k})=$ error waktu sekarang

$\mathrm{E}(\mathrm{k}-1)=$ error satu detik sebelum waktu sekarang

\subsubsection{Low Pass Filter pada Perancangan DOB}

Dalam perancangan sistem kendali dengan Disturbance Observer salah satu komponen penting adalah low pass filter. Filter ini memiliki 2 fungsi yang berbeda, antara lain filter untuk keluaran kontrol PID yang berfungsi untuk mencegah terjadinya aljabar loop yang dapat mengakibatkan kesalahan sistem, sedangkan filter lainnya digunakan untuk keluaran sensor motor yang berfungsi untuk melemahkan sinyal gangguan dari pembacaan sensor motor.

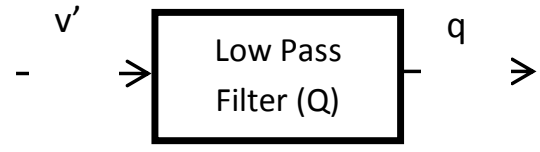

Gambar 12. Blok Diagram Filter Low Pass

Dari gambar blok diagram di atas $v^{\prime}$ adalah masukan filter low pass dan $q$ adalah keluaran filter low pass. Pada penelitian ini filter yang dirancang memiliki frekuensi cut-off( $f c)$ sebesar $5 \mathrm{~Hz}$ dengan frekuensi sampling $(f s)$ sebesar $25 \mathrm{~Hz}$. Ordo filter yang digunakan adalah filter berorde 2 karena sebaiknya minimal berordo sama dengan plant nominal yang berorde 2. Sehingga didapatkan persamaan filter sebagai berikut :

$\tau=\frac{1}{2 \pi f c}$

$\tau=\frac{1}{31.4}=0.03$

$Q(s)=\frac{1}{1+2 x(0.03 s)+(0.03 s)^{2}}$

$Q(s)=\frac{1}{1+0.06 s+0.0009 s^{2}}$

$Q(s)=\frac{10000}{10000+600 s+9 s^{2}}$

Persamaan 19 harus terlebih dahulu ditransformasikan ke dalam domain-z menggunakan Matlab yang mentransformasikan persamaan dalam waktu kontinyu ke persamaan waktu diskrit. Proses transformasi dapat dilihat pada Gambar 13.

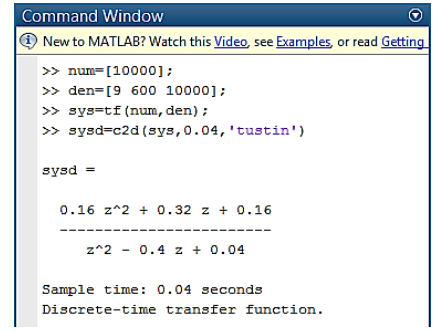

Gambar 13. Proses Transformasi-Z Filter Low Pass

Hasil transformasi-z persamaan 19 dengan mengguakan Matlab diperoleh persamaaan 20 sebagai berikut. 
$Q(z)=\frac{0.16 z^{2}+0.32 z+0.16}{z^{2}-0.4 z+0.04}$

Untuk diubah kedalam bentuk persamaan beda, masing-masing pembilang dan penyebut pada persamaan 20 dibagi dengan $\left(\mathrm{z}^{2}\right)$ sehingga didapatkan persamaan 21 .

$Q(z)=\frac{0.16+0.32 z^{-1}+0.16 z^{-2}}{1-0.4 z^{-1}+0.04 z^{-2}}$

Berdasarkan hubungan masukan dan keluaran dari blok filter low passadalah q=v'x Q.

$\frac{q(z)}{v^{\prime}(z)}=\frac{0.16+0.32 z^{-1}+0.16 z^{-2}}{1-0.4 z^{-1}+0.04 z^{-2}}$

Dari persamaan 22 dilakukan perkalian silang dan didapatkan persamaan 23 .

$q(z)=0.16 v^{\prime}(z)+0.32 v^{\prime}(z) z^{-1}+$

$0.16 v^{\prime}(z) z^{-2}+0.4 q(z) z^{-1}-$

$0.04 q(z) z^{-2}$

Maka persamaan beda dari persamaan 23 adalah sebagai berikut.

$q(k)=0.16 v^{\prime}(k)+0.32 v^{\prime}(k-1)+$

$0.16(k-2)+0.4 q(k-1)-0.04 q(k-2)$

Dimana :

$\mathrm{q}(\mathrm{k}) \quad=$ keluaran filter

$\mathrm{v}^{\prime}(\mathrm{k}) \quad=$ masukan filter sekarang

$\mathrm{v}^{\prime}(\mathrm{k}-1)=$ masukan filter satu detik sebelum masukan filter sekarang

$\mathrm{v}^{\prime}(\mathrm{k}-2)=$ masukan filter dua detik sebelum masukan filter sekarang

$\mathrm{q}(\mathrm{k}-1)=$ keluaran filter satu detik sebelum keluaran filter sekarang

$\mathrm{q}(\mathrm{k}-2)=$ keluaran filter dua detik sebelum keluaran filter sekarang

Sebagai analisis disturbance epada robot digunakan Disturbance Observer yang melakukan koreksi sinyal terhadap gangguan. DOB bekerja pada loop internal yang melakukan koreksi pada bagian plant. DOB memproses sinyal dari sensor rotary encoder dan sinyal keluaran kontrol PID. Hasil pengolahan kedua sinyal tersebut selanjutnya diakumulasi sehingga didapatkan sinyal baru yaitu estimasi gangguan. Blok diagaram Disturbance Observer ditunjukkan pada Gbr 14.

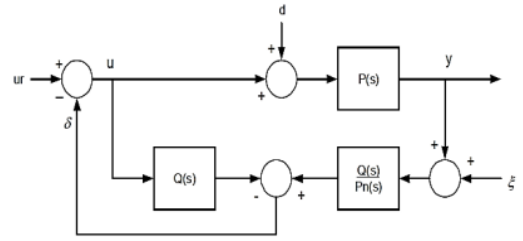

Gambar 14. Struktur Dasar Disturbance Observer

Sinyal $u, d, \xi$ dan $y$ berturut-turut adalah sinyal kontrol, gangguan, noise sensor, dan sinyal keluaran motor. Sinyal $\delta$ merupakan sinyal hasil estimasi. Sinyal ur adalah sinyal kontrol dari kontrol eksternal. $Q(s)$ adalah filter low pass dan $P n(s)$ adalah model nominal plant. Disturbance Observer akan melemahkan sinyal gangguan pada motor yang berfrekuensi rendah sehingga membuat plant aktual motor yang dikontrol oleh kontrol eksternal mendekati model nominal.

$\frac{Q(s)}{P n 1(s)}=\frac{10000 s^{2}+37350 s+1570}{141.21 s^{3}+9453.672 s^{2}+159544.8 s+44080}$

$\frac{Q(s)}{P n 1(s)}=\frac{10000 s^{2}+33070 s+6735}{95.49 s^{3}+6379.743 s^{2}+107016.2 s+15270}$

Persamaan 25 dan 26 digunakan sebagai perancangan kontrol internal motor kanan dan kiri. Kedua persamaan tersebut harus ditransformasikan kedalam domain $\mathrm{z}$ dengan menggunakan Matlab.

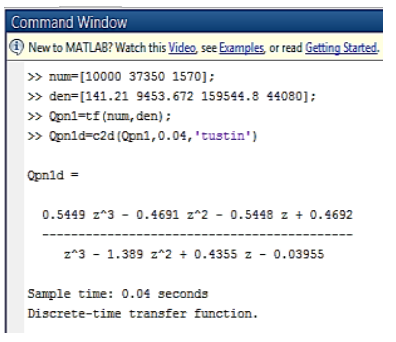

(a)

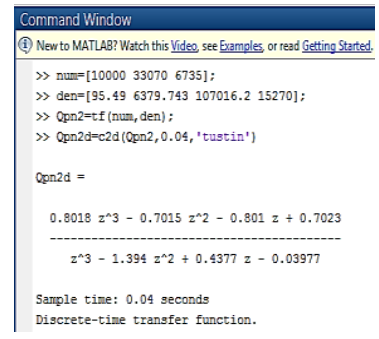

(b)
Gambar 15. (a) Diskritisasi QPn ${ }^{-1}$ Motor Kanan (b) Diskritisasi QPn ${ }^{-1}$ Motor Kiri

Sesuai dengan transformasi (Q/Pn) motor kanan dan motor kiri yang didapatkan dari Matlab didapatkan transformasi domain $\mathrm{Z}$ sebagai berikut: 
$\frac{y^{\prime}(z)}{y(z)}=\frac{0.5449 z^{3}-0.4691 z^{2}-0.5448 z+0.4692}{z^{3}-1.389 z^{2}+0.4355 z+0.03955}$

$\frac{y^{\prime}(z)}{y(z)}=\frac{0.8018 z^{3}-0.7015 z^{2}-0.801 z+0.7023}{z^{3}-1.394 z^{2}+0.4377 z-0.0397}$

Selanjutnya kedua persamaan di atas masingmasing dibagi dengan $z^{-2}$. Sehingga diperoleh persamaan berikut.

$\frac{y^{\prime}(z)}{y(z)}=\frac{0.5449-0.4691 z^{-1}-0.5448 z^{-2}+0.4692 z^{-3}}{1-1.389 z^{-1}+0.4355 z^{-2}-0.03955}$

$\frac{y^{\prime}(z)}{y(z)}=\frac{0.8018-0.7015 z^{-1}-0.801 z^{-2}+0.7023 z^{-3}}{1-1.394 z^{-1}+0.4377 z^{-2}-0.0397 z^{-3}}$

Masing-masing persamaan dikalikan silang, sehingga diperoleh persamaan 31 dan 32 .

$y^{\prime}(z)=0.5445 y(z)-0.4691 y(z) z^{-1}-0.5448 y(z) z^{-2}+$ $0.4692 y(z) z^{-3}+1.389 y^{\prime}(z) z^{-1}-0.4355 y^{\prime}(z) z^{-2}+$

$0.03955 y^{\prime}(z) z^{-3}$

$y^{\prime}(z)=0.8018 y(z)-0.7015 y(z) z^{-1}-0.801 y(z) z^{-2}+$ $0.7023 y(z) z^{-3}+1.394 y^{\prime}(z) z^{-1}-0.4377 y^{\prime}(z) z^{-2}+$

$0.0397 y^{\prime}(z) z^{-3}$

Persamaan dalam domain-z dari persamaan 31 dan 32 diubah ke dalam bentuk persamaan beda agar dapat dimplementasikan pada pemrograman mikrokontroler untuk motor kanan dan kiri.

$y^{\prime}(k)=0.5445 y(k)-0.4691 y(k-1)-0.5448 y(k-$

$2)+0.4692 y(k-3)+1.389 y^{\prime}(k-1)-0.4355 y^{\prime}(k-$

2) $+0.03955 y^{\prime}(k-3)$

$y^{\prime}(k)=0.8018 y(k)-0.7015 y(k-1)-0.801 y(k-2)+$ $0.7023 y(k-3)+1.394 y^{\prime}(k-1)-0.4377(k-2)+$

$0.0397 y^{\prime}(k-3)$

Hasil kedua proses di atas selanjutnya diakumulasi sehingga didapatkan nilai estimasi gangguan. Nilai estimasi gangguan ini selanjutnya diakumulasikan dengan keluaran kontrol PID yang kemudian hasilnya digunakan untuk membangkitkan sinyal PWM untuk masing-masing motor.

\section{Hasil Penelitian}

\subsection{Pengujian Dengan Beban Berbeda}

Dari uji coba baik menggunakan kontrol PID maupun kontrol PID berbasis DOB dengan pemberian beban pada robot sebesar $12 \mathrm{Kg}$. Perbandingan kedua kontrol antara kontrol PID dan Kontrol PID berbasis DOB terhadap nilai acuan ditunjukkan pada Gambar 16. Dari perbandingan respon yang dihasilkan respon motor kanan dengan kontrol PID dan pembebanan seberat $12 \mathrm{Kg}$ memiliki nilai RMSE sebesar 24,65rps. Sedangkan respon motor kanan dengan kontrol PID berbasis DOB memiliki nilai RMSEsebesar 19,39rps. Kemudian respon motor kiri dengan kontrol PID dan pembebanan seberat $12 \mathrm{Kg}$ memiliki nilai RMSE sebesar 18,74 rps. Sedangkan respon motor kiri dengan kontrol PID berbasis DOB memiliki nilai RMSEsebesar 16,92 rps.

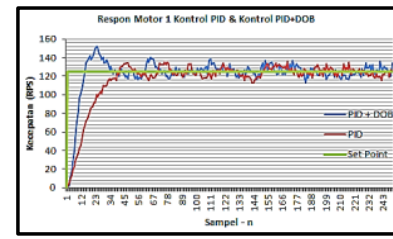

(a)

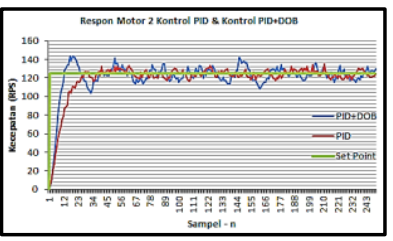

(b)
Gambar 16. a) Respon Motor Kanan Kontrol PID \& PID+DOB

b) Respon Motor Kanan Kontrol PID \& $\mathrm{PID}+\mathrm{DOB}$

Pengujian selanjutnya dengan beban $36 \mathrm{Kg}$ didapatkan hasil perbandingan dari kedua kontrol antara kontrol PID dan Kontrol PID berbasis DOB terhadap nilai acuan ditunjukkan pada Gambar 17.

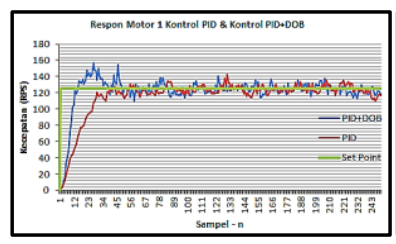

(a)

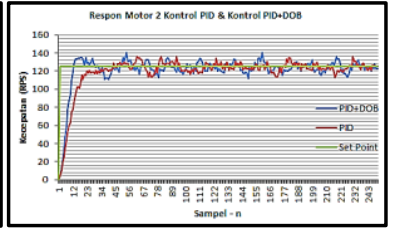

(b)
Gambar 17. a)Respon Motor Kanan Kontrol PID \& PID+DOB

b) Respon Motor Kiri Kontrol PID \& PID+DOB

Dari perbandingan respon yang dihasilkan respon motor kanan dengan kontrol PID dan pembebanan seberat $36 \mathrm{Kg}$ memiliki nilai RMSE sebesar 24,57. Untuk PID berbasis DOB memiliki nilai RMSE sebesar 19,46 rps. Kemudian respon motor kiri dengan kontrol PID dan pembebanan seberat $36 \mathrm{Kg}$ memiliki 
nilai RMSE sebesar 19,15rps. Untuk PID berbasis DOB dan pembebanan $36 \mathrm{Kg}$ memiliki nilai RMSE sebesar 16,51rps.

Untuk lebih jelasnya rangkuman data perbandingan kedua kontrol di atas dapat dilihat pada Tabel 2 .

Tabel 2. Perbandingan kontrol PID dengan PID DOB

\begin{tabular}{|c|c|c|c|}
\hline \multirow[t]{2}{*}{ Gangguan } & \multirow[t]{2}{*}{ Motor } & \multicolumn{2}{|c|}{ RMSE (rps) } \\
\hline & & PID & $\mathrm{PID}+\mathrm{DOB}$ \\
\hline \multirow[t]{2}{*}{ Beban $12 \mathrm{~kg}$} & Kanan & 24.65 & 19.39 \\
\hline & Kiri & 18.74 & 16.92 \\
\hline \multirow[t]{2}{*}{ Beban $36 \mathrm{~kg}$} & Kanan & 24.57 & 19.46 \\
\hline & Kiri & 19.15 & 16.51 \\
\hline
\end{tabular}

\subsection{Pengujian Respon Motor Melewati Tanjakan}

Pada uji coba kali ini robot dijalankan dengan melewati rintangan berupa tanjakan. Spesifikasi tanjakan yang akan dilewati adalah sisi miring segitiga dengan panjang lintasan $150 \mathrm{~cm}$, tinggi segitiga $25 \mathrm{~cm}$, dan sudut kemiringan lintasan sebesar $9,6^{\circ}$. Pengujian dilakukan dengan menganalisa perilaku motor saat robot melewati patahan lintasan.

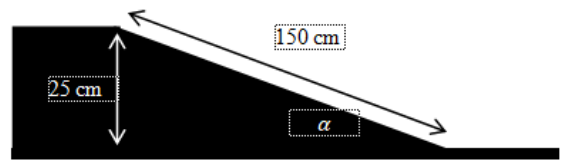

Gambar 18. Lintasan Tanjakan Pengujian Robot

Perbandingan respon motor kanan baik menggunakan kontrol PID dan kontrol PID dengan DOB terhadap set point kecepatan 50 RPS dapat ditunjukkan pada Gambar 19 dengan waktu sampling $40 \mathrm{~ms}$.

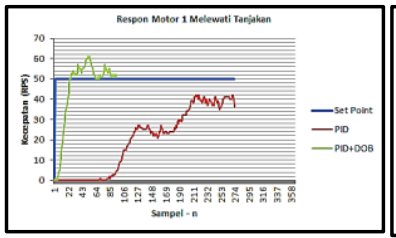

(a)

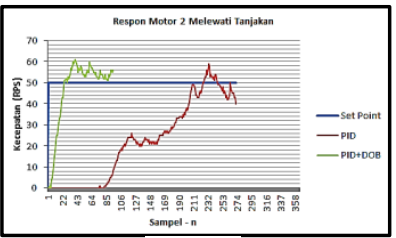

(b)
Gambar 21. a) Respon Motor Kanan Melewati Tanjakkan

b) Respon Motor Kiri Melewati Tanjakkan
Respon motor saat melintasi tanjakkan memiliki nilai RMSE untuk kontrol PID sebesar 1177 rps. Saat robot mulai start respon motor tidak langsung naik, namun membutuhkan waktu yang cukup lama, motor mulai berjalan pada saat sampel ke- 81 x $40 \mathrm{~ms}$ $=3240 \mathrm{~ms}$. Pada saat melewati patahan lintasan, respon motor tidak bisa meningkatkan kecepatannya untuk mencapai nilai set point. Sedangkan nilai RMSEuntuk kontrol PID yang digabungkan dengan DOB sebesar 313 rps. Motor dapat langsung bergerak pada sampel ke-3 x $40=120 \mathrm{~ms}$. Saat melewati patahan lintasan kecepatan motor masih dapat meningkat sampai nilai set point. Selanjutnya pengujian pada respon motor kiri yaitu saat melintasi tanjakkan memiliki nilai RMSE untuk kontrol PID sebesar 1126 rps. Saat robot mulai start respon motor tidak langsung naik, namun membutuhkan waktu yang cukup lama, motor mulai berjalan pada saat sampel ke- 83 x $40 \mathrm{~ms}=3320 \mathrm{~ms}$. Pada saat melewati patahan lintasan, kecepatan motor mulai melambat dan perlahan meningkatkan kecepatannya menuju nilai set point. Sedangkan nilai RMSE untuk kontrol PID yang digabungkan dengan DOB sebesar 292 rps. Motor dapat langsung bergerak pada sampel ke-3 x $40=120$ ms. Saat melewati patahan lintasan kecepatan motor masih dapat meningkat sampai nilai set point.

Detail perbandingan dari kedua kontrol yang digunakan pada masing-masing motor dapat dilihat pada Tabel 3 .

Tabel 3. Perbandingan kontrol PID dengan PID DOB

\begin{tabular}{ccc} 
& \multicolumn{2}{c}{ melewati tanjakan } \\
\cline { 2 - 3 } Motor & \multicolumn{2}{c}{ RMSE (rps) } \\
\cline { 2 - 3 } Kanan & PID & PID + DOB \\
Kiri & 1177 & 313 \\
& & 292
\end{tabular}

Berdasarkan hasil yang didapatkan dapat diketahui pada kondisi ini dengan menggunakan kontrol PID+DOB nilai RMSE dari kedua respon motor memiliki nilai yang sangat kecil sekali yaitu 1/3 dari nilai RMSE PID kontrol tanpa DOB. 


\section{Kesimpulan}

Dengan bertambahnya beban yang membebani motor, maka nilai keluaran kontrol PID akan bertambah besar, hal ini terjadi karena saat pembebanan, seharusnya motor mengalami penurunan kecepatan. Akibat dari penurunan kecepatan ini adalah semakin besarnya error antara nilai acuan kecepatan dan nilai kecepatan motor aktual. Sehigga dengan adanya kontrol Disturbance Observer yang menghasilkan nilai estimasi gangguan akibat pembebanan pada robot, nilai keluaran PID akan turun hingga mendekati 0. Sehingga kontrol PID seolah-olah tidak berperan besar terhadap penjagaan performa motor. Hal ini disebabkan adanya penambahan nilai estimasi gangguan yang dihasilkan Disturbance Observer. Berdasarkan beberapa pegujian yang dilakukan didapatkan rata-rata nilai RMSE kontrol PID maupun PID berbasis DOB untuk motor 1 masing-masing 24,47 dan 19,59 dan untuk motor 2 masing-masing 18,89 dan 16,66. Sehingga pemberian kontrol pada loop internal dengan Disturbance Observer dapat meningkatkan dan menjaga performa motor terhadap ketidak pastian gangguan yang diterima oleh robot terutama pada motor sebagai penggeraknya.

\section{Saran}

Dari sistem yang telah dibuat disarankan menggunakan sensor rotaryencoder dengan resolusi yang lebih besar untuk mendapatkan nilai putaran dan kecepatan yang lebih akurat.

\section{Daftar Pustaka}

[1] Bayu Sandi Marta, "Path Tracking Pada Mobile Robot Dengan Umpan Balik Odometry," Politeknik Elektronika Negeri Surabaya, Surabaya, B.Sc Thesis 2011.

[2] Nita Rachmadyanti, "Kontrol PID Untuk Pengaturan Kecepatan Motor Pada Prototype Ayunan Bayi Otomatis," Politeknik Elektronika Negeri Surabaya, Surabaya, B.Sc Thesis 2011.

[3] Muhammad Ibnu Bahrurrahim, "Rancang Bangun Sistem Kontrol dan Analisa Pengendalian Robot Manual Pada Kasus KRI," Politeknik Elektronika Negeri Surabaya, Surabaya, B.Sc Thesis 2007.

[4] Firdaus, "Rancang Bangun Sistem Kendali Kecepatan Kursi Roda Listrik Berbasis Disturbance Observer," Institut Teknologi Sepuluh Nopember Surabaya, Surabaya, B.Sc Thesis 2011.

[5] Utis Zaenurrohman, "Perancangan Sistem Kontrol Wireless Pada Mobile Robot Manipulator Berbasis Mikrokontroler AT Mega 8," JNTETI Universitas Gadjah Mada, vol. 3, no. 1, pp. 69-75, 2014.

[6] Adelina Kartini, "Sistem Pengaturan Gerakan Tool Pada Prototipe Mesin CNC dengan Kontroler Disturbance Obsrver," Jurnal Teknik POMITS, vol. I, no. 1, pp. 1-6, Juni 2012.

[7] Pramudijanto, Yonatan Ahmad Fatoni, "Perancangan Dan Implementasi Disturbance Observer Untuk Pengaturan Kontur Pada Simulator Mesin Freis ," Jurnal Teknik ElektroFTI, vol. I, no. 1, pp. 1-7, MAret 2005. 